\title{
THE CONTROL PROGRAM OF RED POULTRY MITE (DERMANYSSUS GALLINAE), TODAY
}

\author{
Aleksandar Pavlićević ${ }^{*}$, Radomir Ratajac ${ }^{2}$, \\ Igor Stojanov'2, Ivan Pavlovic ${ }^{3}$ \\ 1 "AVES MIT" LLC, Subotica-Bajmok, Cluster “Dermanyssus gallinae”, Serbia \\ ${ }^{2}$ Scientific Veterinary Institute "Novi Sad", Novi Sad, Serbia \\ ${ }^{3}$ Scientific Veterinary institute of Serbia, Belgrade, Serbia
}

\section{Abstract}

Dermanyssus gallinae control has so far been predominantly based on acaricides (insecticides) and their efficacy has been decreasing in time due to the development of resistance. D. gallinae is a species that has developed resistance to all current acaricides. Considering this, we can assume that the new acaricide - fluralaner with its evident efficacy, but also with some downsides, will improve the situation in D. gallinae control in the short term. The control of red poultry mite population in intensive poultry production has had an unfavourable tendency for decades. In order for this trend to be stopped and reversed, certain measures must be taken to the control of this disease. It is necessary to eliminate toxicological risks; define the short-term objective (efficient suppression) and the long-term one (eradication); introduce the principles of biosecurity, prevention, and rational control; provide a professional application of formulations and increase the quality of monitoring. The D. gallinae program control integrates all the above specified elements into a whole. In our opinion, the currently used program currently used on farms, based on mechanical control and active influence on technological processes, has a bright future. This type of control can be combined with other efficient methods of mite suppression on farms.

Key words: program, control, Dermanyssus gallinae

${ }^{1 *}$ Corresponding author: zemljadrveca@gmail.com 


\title{
ПРОГРАМСКА КОНТРОЛА ЦРВЕНЕ КОКОШИЈЕ ГРИЊЕ (DERMANYSSUS GALLINAE), ДАНАС
}

\author{
Aleksandar Pavlićević ${ }^{*}$, Radomir Ratajac ${ }^{2}$, \\ Igor Stojanov', Ivan Pavlovic ${ }^{3}$ \\ 1 “AVES MIT” LLC, Subotica-Bajmok, , Klaster “Dermanyssus gallinae”, Srbija \\ ${ }^{2}$ Naučni institut za veterinarstvo "Novi Sad”, Novi Sad, Srbija \\ ${ }^{3}$ Naučni institut za veterinarstvo Serbia, Beograd, Vojvode Toze 14, Srbija
}

\section{Kratak sadržaj}

Kontrola D. gallinae se do sada dominantno zasnivala na akaricidima (insekticidima), čija efikasnost je tokom vremena slabila zbog razvijanja rezistencije. D. gallinae je vrsta koja je razvila otpornost na sve do sada korišćene akaricide. Sa tog stanovišta, predpostavka je da će novi akaricid fluralaner, i pored evidentne efikasnosti, ali i nedostataka, dovesti do kratkotrajnog poboljšanja situacije u kontroli D. gallinae. Kontrola populacije crvene kokošije grinje u živinarskoj proizvodnji tokom više decenija ima nepovoljnu tendenciju, i da bi taj trend zaustavili i preokrenuli u drugom smeru, moraju se preduzeti određene mere u samom pristupu kontroli ove bolesti. Potrebno je: isključiti toksikološke rizike; odrediti kratkoročan (efikasnog suzbijanja) i dugoročan cilj (eradikacije); uvesti principe biosigurnosti, preventive i racionalne kontrole; obezbediti stručnu primenu formulacija i povećati kvalitet monitoringa. Navedene elemente u celinu objedinjuje program kontrole D. gallinae. Aktuelni program koji se koristi na farmama i po našem mišljenju ima perspektivu, bazira se na fizičkoj kontroli i aktivnim uticanjem na tehnološke procese. Takav vid kontrole je moguće kombinovati sa drugim takođe efikasnim metoda suzbijanja grinja na farmama.

Ključne reči: program, kontrola, Dermanyssus gallinae

\section{INTRODUCTION}

Dermanyssus gallinae is the most significant poultry ectoparasite (Figure 1). The results of several decades of control are the following: high prevalence (Sparagano et al, 2009), health problems disturbance, stress, impact on the general health status of the flock (Emous 2005; Kowalski and Sokol, 2005; Kaoud, 2010), progression of conditional diseases, transferring agents of infec-

${ }^{{ }^{*}}$ Autor za korespondenciju: zemljadrveca@gmail.com 
tious diseases (Moro et al, 2005, Huong et al, 2014), decrease in production results, increase of economic loss (Emous 2005, 2017; Flochlay et al, 2017) and evident toxicological risk to human health (Marangi et al, 2012; Giangaspero et al, 2011, 2017), poultry health and the environment. The extent and tendency of all the above mentioned factors prove that current $D$. gallinae control is inadequate and the approach is improper.

"The extent to which the probability of events has changed under the influence of a message can be used as a measurement of the quantity of information contained in that message"- this is an interpretation from the mathematical information theory by Shannon (1948). In addition to the information about the current situation in D. gallinae control, we will provide two more examples. In the last few decades of the $20^{\text {th }}$ century, an intensive development of poultry industry started. This is when timely information about the risk and possible spreading of $D$. gallinae should have been provided.

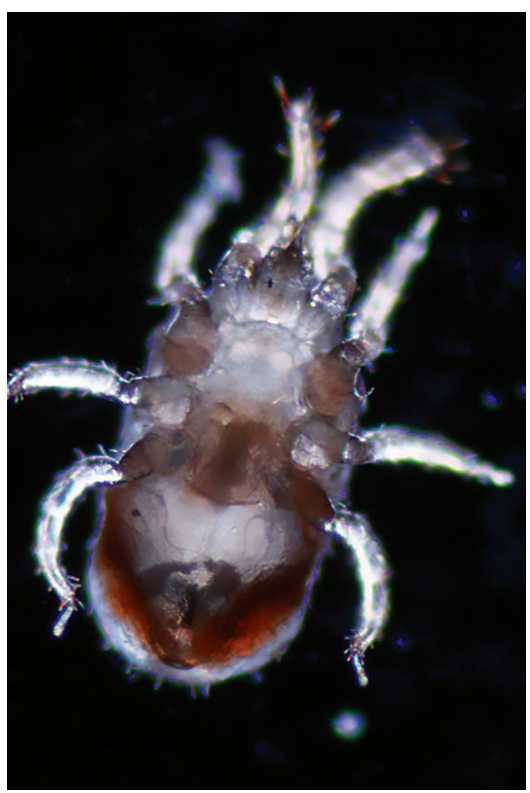

Figure 1. Dermanyssus gallinae

Biosecurity measures should have been introduced and mass farm infestations would have been prevented. This information was not provided, and the consequences of this failure are now widely known. The second example is the change of the conventional cage system for housing layers in the EU. That was the moment when the eradication of $D$. gallinae could have easily been affected 
in old poultry houses or initial infestation could have been prevented in newly built ones. Despite an extraordinary opportunity to change the situation, necessary information was again not provided. The aim of this paper is to point out the chance to change the widely accepted approach to D. gallinae control in order to stop the unfavorable trend, improve practical results, and direct the development towards the permanent solution.

\section{THE BASIC PRINCIPLES OF THE PROGRAM APPROACH FOR CONTROL OF RED POULTRY MITES}

The existing D. gallinae control needs improvement (Schulz et al, 2014a; Pritchard et al, 2015; Flochlay et al, 2017). Most products for D. gallinae control available on the market are not efficient enough. However, even an efficient product is not sufficient for successful control on its own. It also needs to be properly applied. Furthermore, what is necessary is a program - a comprehensive plan that would have a properly defined objective and that would tackle all other factors important for the control. The importance of a program approach to $D$. gallinae control is rarely emphasized, and the efforts to design and implement a program are rarely made. Emous (2005) lists 4 main elements of a program: thorough cleaning of a poultry house between two flocks, prevention of a new infestation, constant monitoring and implementation of efficient control methods. This program proscribed monitoring on a weekly basis (checking the same 20-30 spots) and its aim was suppression. Users are not familiar with its practical value.

The program approach to D. gallinae control has been developed in Serbia since 2000 (Pavlićević et al, 2018a).

The objectives of the program are the following:

1. To prevent D. gallinae infestation on uninfected farms

2. On infested farms: a) primarily to eliminate safety risks and introduce rational control, and then to raise the level of efficacy and cost-effectiveness of D. gallinae control in the short term b) to eradicate D. gallinae from production facilities and farms and to introduce biosecurity measures in the long term.

The task of the program is to get a comprehensive overview of all important questions in D. gallinae control and to provide the answers. It should cover the following areas: D. gallinae biology; environmental characteristics of poultry farms; laboratory tests and clinical trials; detection and monitoring; choice of formulations and methods; preparation of farms and professional application 
and introduction of biosecurity measures. This task should be completed in accordance with the principles of preventive veterinary medicine and rational D. gallinae control. The program helps to obtain and share important information. Providing quality information to experts and farmers is a way for them to be properly involved in the control program and make an active contribution to the solution.

\section{LIFECYCLE, PHYSIOLOGY OF D. gallinae AND IMPACT ON THE EFFICIENCY OF THE CONTROL}

D. gallinae biology itself determines the approach and procedure of the control program:

1. Adults are the most problematic stage of D. gallinae on which the control measures are focused. They have a great ability to survive. The reasons for this are: ability to hide, mobility, receptors, ability to starve (in some cases for more than a year - Pavlićević et al, 2007), tolerance to environmental conditions (Nordenfors et al, 1999), possibility of alternative nutrition (Nordenfors, 2000).

2. Due to their ability to hide, a prolonged effect of the formulation or method is the key property of an efficient product (Pavlićević et al, 2016). High efficacy on directly exposed mites is obligatory, because without that there is no prolonged effect either.

3. Eggs are resistant to some formulations, but in a properly designed program, this bears no clinical significance. This is due to the fact that egg development is continuous and short (usually from 1 to 3.2 days, depending on the environmental conditions - Nordenfors et al, 1999), and the next developmental stages soon become exposed to the formulation residual effect.

4. Control efficacy must be high due to the great reproductive potential (Pavlovic et al, 2017) and short life cycle of D. gallinae (Nordenfors, 2000).

5. D. gallinae develops resistance to insecticides (acaricides), but also adapts in other ways (Ebeling, 1971; Zeman and Zelezny, 1985; Zeman, 1987; Marangi et al, 2012; Pavlićević, 2005; Pavlićević et al, 2016; 2018a; Abbas et al, 2014).

6. Molecular diagnostic tests showed that infestation mostly originates from the intensive poultry production, whereas $D$. gallinae originating from the natural environment is secondary (Roy, 2009). This information is important for biosecurity. With the change in the method of poultry housing, infestation from the nature could become more significant. 


\section{THE ENVIRONMENT}

The environment is one of the key factors in D. gallinae control program (Figure 2.). Experts assessed the changes in the method of layer housing in the EU as unfavorable from the aspect of D. gallinae control (Flochlay, 2017). In addition to that, the existing practice in D. gallinae control does not pay enough attention to the importance of the farm's environment. Not only the method of layer housing, but also the complexity and construction of some models of cages and equipment impose very demanding conditions for D. gallinae control, so farmers have long-term indirect losses if they buy those. Poultry experts have not warned farmers about these cases. Regarding D. gallinae control, simplicity and functionality are the requirements for every manufacturer of cages and equipment. The model Q - Perch by Vencomatic is designed for active D. gallinae control (Dick van de Ven, 2016). The efficacy of this concept is questionable. This approach is not in accordance with the control program that proscribes only security measures for new farms.

In previously used infested poultry houses, the change of cages and equipment provides good conditions for the eradication of D. gallinae, and subsequently the introduction of biosecurity measures. The program is especially being developed in the direction of improving the environmental conditions, and in the upcoming period we are expecting results in this area.

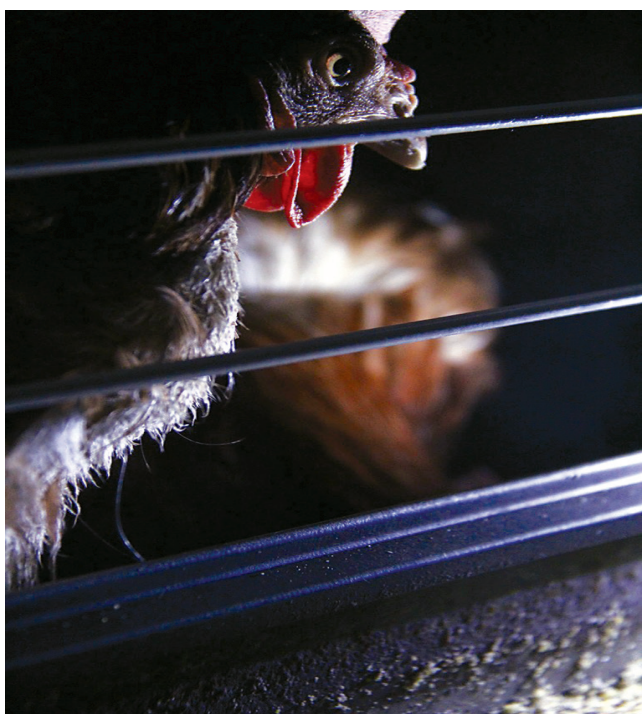

Figure 2. An example of improved environmental conditions - the deep gutter on the inner edge of the feed trough is irrelevant for D. gallinae control if it is permanently filled with a neutral substance 


\section{EFFICACY OF FORMULATIONS}

Information on the efficacy of formulations and methods is provided by laboratory tests and clinical trials. Laboratory tests need to determine the effect of a formulation on directly exposed mites, residual effect (on subsequently exposed mites on the treated surface) and resistance (in cases when it occurs). The information we obtain in the lab has a limited, approximate significance. We can form a full profile of a formulation only through clinical trials. The results of clinical trials are influenced by the effect of the formulation, and by other factors depending on the specific conditions as well. Because of this, various factors need to be included and perceived comprehensively by repeating the tests in different conditions. The following factors need to be acknowledged in clinical trials: the results of laboratory tests of the formulation; housing technology; complexity and structure of the environment; hygienic conditions; temperature and humidity (time of year); infestation intensity and extensity; application (the moment of application, concentration and dosage, method of application, controllability); presence of adaptation systems; length of the housing down time; biosecurity measures; monitoring; side effects, flaws, complications and, if necessary, other. The final assessment of a formulation's efficacy should include the whole production period of a layer, a full year (Pavlićević, 2018b).

\section{THE RIGHT CHOICE OF FORMULATION AND METHODS OF D. gallinae CONTROL}

Laboratorytestsand clinicaltrialsprovideinformation whichisusedinaccordance with the criteria of rational control to choose the formulation and method. The choice of the formulation and method should be based on the arguments of safety, efficacy, and cost-effectiveness. In addition to this, it is necessary to define all other features relevant for the successful application in practical conditions.

Prior to the external application of formulations, poultry housing needs to undergo a detailed hygienic preparation, cleaning, washing and disinfection. After the housing has been examined and all necessary conditions fulfilled, a formulation is applied with care. Together with the choice of formulations and methods of $D$. gallinae control, professional application is another precondition for successful control. If necessary, auxiliary measures are taken simultaneously in order for the procedure to be a complete success. 


\section{MONITORING THE EFFICACY OF D. gallinae CONTROL}

Detection and monitoring provide a relevant insight into the presence of D. gallinae and infestation intensity and extensity. Detection procedure can be based on methods that provide information from a wider area or from specific spots. An example for the latter are traps, which require multiple repetitions and adequate timing of assessment in order to provide reliable information. Visual examination and early dust detection (in cage systems) are particularly operative methods (Pavlićević et al., 2017). We advocate comprehensive monitoring (staff's observations, anamnestic data, flock's health status, production results) and multiple detection methods which should be implemented throughout the production period at monthly intervals (or more frequently, if necessary). Descriptive presentation of results is preferable to numerical. Complex diagnostic methods such as automated mite counter for Dermanyssus gallinae (Mul et al, 2015) are unnecessary expenditures for farmers and we do not think they are justified.

\section{BIOSECURITY MEASURES}

Biosecurity measures are supposed to prevent the introduction of D. gallinae into the farm or into the poultry house. This measure is essential to the program. It reaches its full purpose in uninfected facilities, and in the examples where eradication has been successfully performed. In infested facilities, biosecurity measures can enhance the effects of suppression. For the biosecurity to be effective, it needs to be based on timely, accurate, and complete information. It is implemented outside and inside the farm alike. The factors that are particularly important for biosecurity in D. gallinae control are population of a young flock (the flock itself and transportation cages), removing old flock (transportation cages and vehicles) and purchasing used cages and equipment. When purchasing a young flock, it is important to carry out the forensic assessment correctly. Dermanyssosis is a hidden fault and if not looked for, it usually goes unnoticed. Debris from transportation cages should be shaken off the cages, collected and covered with paper. In the end it should be unloaded and inspected in the presence of the supplier (Pavlićević et al., 2003).

\section{INTEGRATED PEST MANAGEMENT / INTEGRATED HEALTH CARE (IPM/ IHC)}

The integrated pest management (IPM) Axtell approach (1998) includes measures that would integrate pest management in the poultry industry: iden- 
tification, monitoring and control. The control program is in accordance with the mentioned principles. In large infestations $D$. gallinae can coexist with the housefly - Musca domestica (Pavlovic et al, 2016), and very frequently with rodents. P 547/17 has a general acaricide and insecticide effect. However, a more significant coordination with the program is yet to be performed. The development of the program is directed towards integrated health care (IHC), especially by connecting and integrating into the general health care, disease control and toxicology (Pavlićević et al, 2018a,b,c). External machine application of formulations has been successfully performed in order to improve the application of disinfectants. The reasons are excluding manual labor and human error as well as being functional. Disinfection in the true sense of the word cannot be considered successful if there are infestation vectors left in the environment. Therefore, D. gallinae control measures need to be synchronized with disease control (Moro et al, 2005; Huong et al, 2014). We must emphasize the significance of salmonellosis that can parasitize in D. gallinae for up to 4 months (De Luna, 2008). Housing down time imposed in case of infectious disease can be used to eradicate D. gallinae (Pavlićević et al, 2018a).

\section{THE ULTIMATE GOAL OF THE PROGRAM FOR THE CONTROL OF THE POULTRY RED MITE}

The possibility of $D$. gallinae eradication from production facilities is the key issue for red poultry mite control, and it is rarely mentioned and considered. The generally accepted expert approach states that eradication is not possible. The control program proves that it is (Pavlićević et al, 2018a). Eradication is the ultimate goal of the program and the final solution for D. gallinae control. It eliminates toxicological risk arising from inadequate $D . \mathrm{gal}$ linae control, the role of $D$. gallinae vectors in intensive poultry production, the adverse effect of D. gallinae on the flock's health status. Also, to the greatest possible extent, it protects farmers' economic interest, consumers' health and economic interest and farm staff's interest. Finally, it prevents the development of resistance and further spreading of dermanyssus.

\section{THE CURRENT SELECTION OF ACTIVE SUBSTANCES}

The control program (in the narrow sense) is based on mechanical effect, especially on inert substances and during the housing preparation period before the population of the flock. $\mathrm{SiO} 2$ formulations are an alternative to acaricides (Kilpinen and Steenberg, 2009; Schulz, 2014a). Their effect focuses on 
the absorption by the mites' epicuticular layer and the subsequent dehydration (Ebeling, 1971). In some $\mathrm{SiO}_{2}$ formulations necessary properties have been recorded in lab conditions (Schulz et al, 2014b) and confirmed in practice (Pavlićević et al, 2018b). There are pros and cons of powdered and liquid forms. What is original in the program of " $D$. gallinae", Cluster, Serbia is the combined application of both liquid and powdered forms of $\mathrm{SiO}_{2}$. Optimization of their application includes the correct choice of formulations and their combined professional application in both forms during the housing preparation, when there is sufficiently long down time in the temperature conditions when mites are active. Application of powdered and liquid forms of $\mathrm{SiO}_{2}$ requires special applicators and expertise. Too complex cages and equipment question the rationality of the procedure. In a populated house efficacy is low due to the problem of formulation distribution, low penetrability into the dirt, small biocide capacity per surface unit, the ability to lay eggs even in lethally exposed mites, removing and compromising of the surface layer, influence of moisture (Pavlićević et al, 2018b). Even though successful results of $\mathrm{SiO}_{2}$ during preparation period have been confirmed, their flaws and demanding application have limited their use to the smaller part of the poultry industry. The flaws have mostly been corrected with the new generation of inert substances $P$ 547/17 (product Pulcap, manufacturer Pulsil LLC“ D. gallinae" Cluster, Serbia) - Pavlićević et al, 2018a,b,c). The P 547/17 is an emulsion concentrate applied in the form of $20 \%$ water emulsion (Figure 3 ). It is used for the preparation of cages, equipment and environment in general. It is registered as a product for general use. It is not abrasive and does not require special applicators, but the existing spraying applicators for water solutions can be used if they contain the mechanism for mixing while in operation. P 547/17 immobilizes directly exposed mites and prevents D. gallinae respiration. Moreover, it probably penetrates the body and disturbs life functions of D. gallinae. Comprehensive effect of the formulation on D. gallinae is yet to be tested. So far, it is based on the general information about the effect of oils (Agnello, 2002). Liquid form of the emulsion enables better distribution and penetrability. In addition to the high efficacy on directly exposed mites, on unabsorbent surfaces, it forms a layer with long extended effect which is most emphasized in empty poultry houses. Lab tests and clinical trials show that P 547/17 has the necessary properties for highly efficient suppression, but also the potential for eradication (Pavlićević et al, 2018c). The first cases of eradication were recorded in practical conditions (2). Performing eradication in complete systems of intensive poultry production will start in Serbia in 2019 as part of the project funded by The Innovation Fund Serbia (ID = 1115), "Red poultry mite control with a mixture of 
inert oils". It will include two production cycles of table eggs with the capacities of 400,000 and 200,000 layers. With the optimization of this concept and the development of the next stages of mechanical control, in the future it will be possible to completely exclude synthetic neurotoxic compounds from egg production.

D. gallinae control program focuses on mechanical methods and housing preparation. In production systems, the program starts on rearing farms. After the rearing finishes, poultry housing is prepared for the production period. A young, uninfested flock is populated in the poultry housing, using uninfested transportation cages. Formulation P 547/17 is proscribed for the treatment of transportation cages, and, if necessary, for used cages and equipment. For the procedure of $D$. gallinae eradication, an important factor is the housing down time (a break after cleaning, washing, disinfection and applying a layer of the substance) in temperature conditions that enable the mite activity. The recommended length of the down time is 14 days, and optimally 30 days (these figures are approximate, and depend on the temperature conditions).

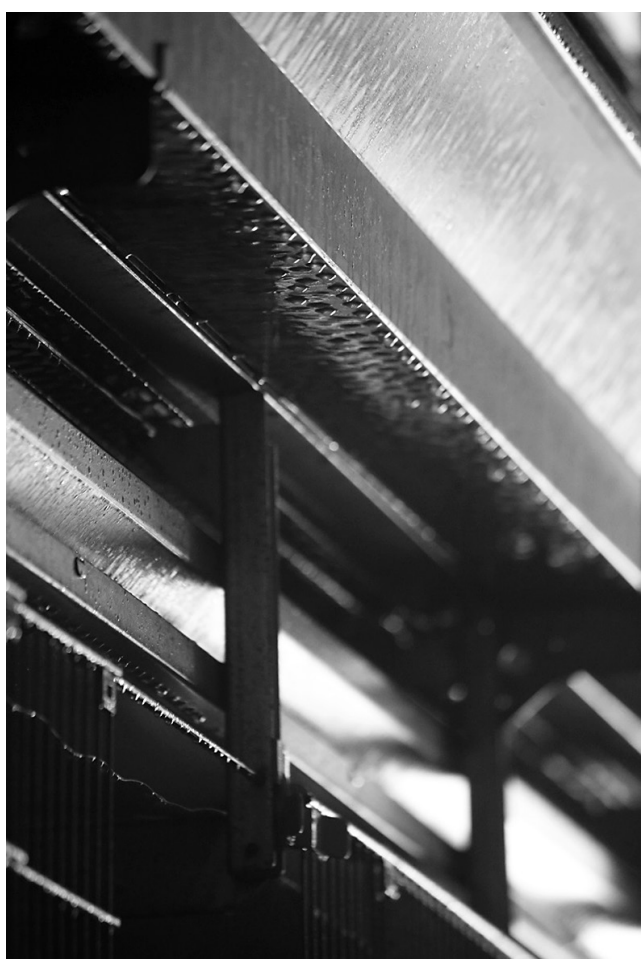

Figure 3.A cage covered with a layer of Pulcap 
Veterinary profession obliges us not only to work on long-term development, but also to constantly look for short-term answers to all the situations that are pressuring the poultry industry. Because of this, in addition to the basic direction of development based on mechanical control, it is our task to adapt the eradication procedure to the current moment and make it less demanding and thus more available for farmers. Especially for those farms where the environmental conditions of alternative methods of layer housing have made D. gallinae control more difficult. Isoxazoles are insecticides with specific effect. The assessment of their insecticide potential is announced as "the golden age" (Casida, 2015). Isoxazol Fluralaner is potent inhibitor of parts of arthropod nervous system and acts antagonistically on ligand-gated chloride channels (GABA- receptor and glutamate-receptor). It is registered as a veterinary medicine Exzolt, made by MSD Animal Health. It is administered in drinking water in the dosage of $0.5 \mathrm{mg}$ of fluralaner $/ \mathrm{kg} \mathrm{BW}$, twice over the period of 7 days. When applied in this way, Exzolt starts to produce its effect in 4 hours, and it reaches its full effect over the period of 14 days, including two development cycles of D. gallinae (Technical Manual, Exzolt, MSD Animal Health). However, in our opinion, this residual effect (14 days) is not long enough for a complete $D$. gallinae control. In practical conditions, the development cycle lasts longer than the period stated in the manual for this medicine, which is the minimal length of D. gallinae cycle. For example, at the temperature of $25^{\circ} \mathrm{C}$ the development of a D. gallinae generation will end in 16.8 days (Maurer and Baumgartner, 1992). This lasts even longer in winter, at least for the part of the infestation located in the lower levels of cages, floors and walls. In infestations of high intensity and extensity, D. gallinae distribution also includes places which are not in the immediate vicinity of hens. Those mites do not have the same feeding dynamics as those close to the hens, which is proven by their colour and dimensions. Toxicological opinion prevents any repeated treatments with the same veterinary medicine within the period shorter than 3 months (instructions for application of Exsolt, MSD Animal Health). Efficacy of fluralaner recorded in laboratory conditions is $90 \%$ mortality $\left(\mathrm{LC}_{90}\right)$ values, the laboratory isolate was susceptible to fluralaner (15.6-62.5 parts per million, ppm). Mite $\mathrm{LC}_{90}$ when exposed to fluralaner by blood feeding was < $0.1 \mathrm{ppm}$ (Thomas et al., 2017) and in clinical conditions $99.99 \%$ in 4 weeks (Sleeckx et al., 2018), and suppression effect ranges from 56 to 238 days (Thomas et al, 2018). Despite the obvious efficacy manifested by fluralaner, at the same time, it has evident flaws. In cases where conditions for optimal application of inert substances cannot be ensured, it is suggested that inert substances be applied in combination with veterinary medicines based on the 
insecticide fluralaner (Pavlićević et al, 2018a). Correct application of insecticides can exclude any further insecticide use, prevent frequent treatments and slow down the development of resistance. The whole procedure needs to be optimized and confirmed in practice. Program application of the chosen inert substances and the new veterinary medicine based on the active substance fluralaner at this moment provides the necessary preconditions for Dermanysossis to become a controllable health and economic problem. Otherwise, we expect that fluralaner application as currently prescribed, will cause resistance and prevent its further use in the purpose of achieving full efficacy. Therefore, we should immediately switch to its controlled and planned application in the form of a program.

\section{COST BENEFIT ANALYSIS}

Despite larger initial expenditures and more effort, eradication is cost-effective for farmers because in this way they can eliminate further spending. We will take a farm of 100,000 hens as an example. Total expenditures incurred by D. gallinae are estimated at $€ 0.6$ per hen (Emous, 2017; Flochlay et al, 2017). If we take $0.5 €$ per hen as the annual expenditure caused by red poultry mite, the total amount will be 50,000 $€$. In case of eradication, this farm would save half a million euros in ten years.

\section{HOW TO CONTRIBUTE TO THE IMPLEMENTATION OF THE PROGRAM?}

Reporting D. gallinae infestation in poultry houses would be useful for multiple reasons. It would provide information and practical protection for uninfected farms and prevent re-infestation in cases of eradication. It would differentiate the prices of infested and uninfected young flocks and motivate farmers to design a plan of eradication. It would also improve the residue monitoring, provide a continual overview of prevalence, enable the preparation for systematic implementation of D. gallinae control program on horizontal and vertical levels, provide assessment of effects of the implemented control measures and monitor the influence on the flock's health status, especially infectious diseases (Pavlićević et al, 2018a). Furthermore, there is a need for an international scientific-expert-business project that would take responsibility for control results on poultry farms, suggest the choice of formulations and methods in accordance with the principles of rational control, and provide adequate application and monitoring in practice. This way it would eliminate 
errors that cause health and economic problems, and actively protect the common interest of the poultry industry. At the same time it would contribute to the development of formulations and methods until the final solution of this problem is found (Pavlićević et al, 2018d).

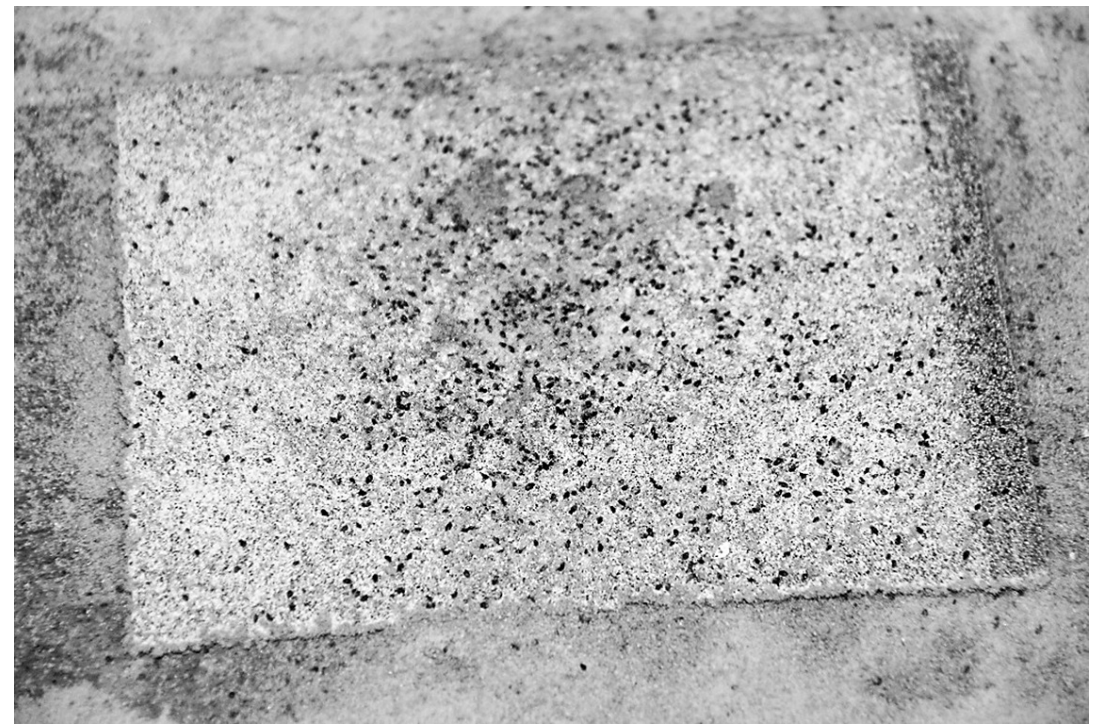

Figure 4. Mites extinct due to a disease of unknown etiology

\section{FINAL CONSIDERATIONS AND EXPECTATIONS}

The approach for the control of the poultry red mite has resulted in inadequate control of $D$. gallinae to date. We suggest that existing practice be improved by adopting the D. gallinae program control principle. Conditions have been met for Dermanysossis to become a controlled health and economic problem.

In the future it will be possible to completely exclude all synthetic neurotoxic compounds from egg production. We are expecting new improvements of the control program, especially in the field of mechanical control. In addition to this, there is a great potential in studying mite diseases that can cause the extinction of mites in poultry houses (Figure 4.). This phenomenon was recorded in the clinical experience in Germany, Italy and Serbia during the summer period.

The program is open to all new improvements of $D$. gallinae control. Regular tasks are constant testing of new formulations and methods, reviewing, improving and adapting the program to farms' specific conditions and needs. 


\section{REFERENCES}

1. Abbas RZ, Colwell DD, Iqbal Z, Khan A.: Acaricidal drug resistance in poultry red mite (Dermanyssus gallinae) and approaches to its management. Worlds. Poul Science Journal, 70, 113-24, 2014.

2. Agnello, A.M.: Petroleum - Derived spray oils: chemistry, history, refining and formulation. In: Spray Oils Beyond 2000, University of Western Sydney Press, Australia, 2-18, 2002.

3. Casida J.E.: Golden age of RyR and GABA-R diamide and isoxazoline insecticides: common genesis, serendipity, surprises, selectivity, and safety. Chemical Research in Toxicology, 28(4), 560-6, 2015.

4. Dick van de Ven (2016): Q-Perch, electronic control of red mite. Vencomatic Group. In: Abstarct book, 2nd COST ACTION FA1404. Improving current understanding and research for sustainable control of the poultry red mite Dermanyssus gallinae (COREMI), 1st -3rd June, Zagreb, Croatia, 2016, p24

5. Ebeling W.: Sorptive dusts for pest control. Annual Review of Entomology, 16, 123-158, 1971.

6. Emous Van, R.: Wage war against the red mite! Poultry International, 44 (11), 26-33, 2005.

7. Emous Van R. Verwachtte schade bloedluis 21 miljoen euro. Pluimveeweb. nl. 2017. https://www.pluimveeweb.nl/artikelen/2017/01/schade-bloedluis21-miljoen-euro/. Accessed 17 Jan 2017.

8. Exsolt, Fluralaner E. MSD Animal Health. Guidelines for the use of veterinary medicines $191818 \mathrm{R} 3$.

9. Flochlay A.S., Thomas,E., Sparagano O.: Poultry red mite (Dermanyssus gallinae) infestation: a broad impact parasitological disease that still remains a significant challenge for the egg-laying industry in Europe. Parasites \& Vectors 10:357, 2017. DOI 10.1186/s13071-017-2292-4.

10. Giangaspero A., Marangi M., Pati S., Cafiero M.A., Camarda C., Sparagano O.A.E.: Investigating the Presence of Acaricide Residues in Laying Hens Naturally Infected by the Red Mite Dermanyssus gallinae. The 12th Asian food conference 2011, 16 -18 June, BITEC Bangna, Bangkok, Thailand, 2011, p76

11. Giangaspero, A., Bartley K., Mul M., Papadopoulous E., Roy L.,Horvatek Tomic, D.; Sparagano, O.: The anarchy in chemical control of Dermanyssus gallinae, and the need to establish specific EU regulations: the efforts of a COST Action // WVPA XXth Congress 2017 Book of Abstract, Edinburgh, UK, 2017, p35. 
12. Huong C.T., Murano T., Uno Y., Usui T., Yamaguchi T.: Molecular detection of avian pathogens in poultry red mite (Dermanyssus gallinae) collected in chicken farms. The Journal of Veterinary Medical Science, 76 (12), 1583-7. 2014

13. Kaoud H.A., El-Dahshan R.A.: Effect of Red Mite (Dermanyssus gallinae) Infestation on the Performance and Immune Profile in Vaccinated broiler breeder flocks. Journal of American Science, 6(8), 72-78, 2010.

14. Kilpinen, O., Steenberg T.: Inert dusts and their effects on the poultry red mite (Dermanyssus gallinae). Experimental and Applied Acarology, 48, 51-62. 2009.

15. Kowalski A, Sokol R.: Influence of Dermanyssus gallinae (poultry red mite) invasion on the plasma levels of corticosterone, catecholamines and proteins in layer hens. Polish Journal of Veterinary Science, 12,231-5, 2005.

16. Marangi M, Morelli V, Pati S, Camarda A, Cafiero MA.: Acaricide Residues in Laying Hens Naturally Infested by Red Mite Dermanyssus gallinae. PLoS ONE 7(2): e31795, 2012. doi:10.1371/journal.pone.0031795.

17. Maurer, V., Baumgärtner, J.: Temperature influence on life table statistics of the chicken mite Dermanyssus gallinae (Acari, Dermanyssidae). Experimental \& Applied Acarology, 15, 27-40, 1992.

18. Moro V.C., Chauve C., Zenner L.: Vectorial role of some Dermanossoid mites (Acari, Mesostigmata, Dermanyssoidea). Parasite, 12, 99-109, 2005.

19. Mul F. M., van Riel J.W., Meerburg B.G., Dicke M., George D.R., Groot Koerkamp P.W.G.: Validation of an automated mite counter for Dermanyssus gallinae in experimental laying hen cages. Exprerimental and Apply Acarology, 66, 589-603, 2015.

20. Nordenfors H, Höglund J., Uggla A.: Effects of temperature and humidity on oviposition, molting and longevity of Dermanyssus gallinae (Acari: Dermanyssidae). Journal of Medicinal Entomology, 36 (1), 68-72, 1999.

21. Nordenfors H. (2000). Epidemiology and Control of the Poultry Red Mite, Dermanyssus gallinae; PhD thesis, Swedish University of Agricultural Sciences; Uppsala.

22. Pavlićević A., Petričević S., Pavlović I., Stajokvić N., Pižurica A.: Prilog forenzičkoj proceni dermanisoze (Dermanyssosis). Vet. glasnik 57 (7-8), 517-523, 2003.

23. Pavlićević A.: Testing akaricidnog effects of cypermethrin in the control of D. gallinae. Postgraduate Veterinary Specialist thesis, Faculty of Veterinary Medicine University in Belgrade, 2005.

24. Pavlićević A., Pavlović I., Dotlić M.: A contribution to information on starvation survival capacity of poultry red mite Dermanyssus gallinae. Lucrari 
Stiintifice Medicina Veterinara, 50 (9), 485-491, 2007.

25. Pavlićević A., Pavlović I., Stajković N. Bratislav P.: Evidence for Resistance to Carbaryl in Poultry Red Mites from the Republic of Serbia and Montenegro. Scientific Papers: Animal Science and Biotechnologies, 49 (1), 222225, 2016.

26. Pavlićević A., Ratajac R., Dotlić M., Stojanov I., Pavlovic I.: An innovative formulation of paraffin and silicone oils for the control of the red poultry mite (Dermanyssus gallinae) - examination of the efficiency under laboratory conditions. Arhiv veterinarske medicine, 10 (2), 63 - 79, 2017.

27. Pavlićević A., Radomir R., Horvatek Tomić D., Stojanov I., Pavlović I.: Dermanyssus gallinae eradication approach - application of inert compounds and integral animal health protection. Arhiv veterinarske medicine, 11 (1), 3-15, 2018a.

28. Pavlićević A., Ratajac R., Stojanov I., Pavlovic I.: Innovative Formulation Of Paraffin And Silicon Oils For The Control Of Poultry Red Mite (Dermanyssus gallinae) - 3. Comparative Clinical Examination of Efficacy with Active Matter SiO2. Invention Journal of Research Technology in Engineering \& Management, 2 (10), 24-30, $2018 \mathrm{~b}$.

29. Pavlićević A., Ratajac R., Dotlić M., Stojanov I., Pavlovic I. Horvatek Tomić D.: New generation of inert substances in D. gallinae control. „XV European Poultry Conference“, Dubrovnik, 17th - 21st September 2018, Croatia. World Poultry Science Journal 73, supplement 1, 528, $2018 \mathrm{c}$.

30. Pavlićević A., Ratajac R., Stojanov I., Pavlovic I.: Program control of poultry red mite dermanyssus gallinae, today. Scientia Parasitol 19, Special issue, 32-33, 2018d.

31. Pritchard J., Kuster Tatiana, Sparagano O., Tomley F.: Understanding the biology and control of the poultry red mite Dermanyssus gallinae: A review. Avian Pathology, 44(3), 143-153, 2015.

32. Roy L.: Ecologie evolutive d'un genre d'acarien hematophage: approche phylogenetique des delimitations interspeciques et caracterisation comparative des populations de cinq especes du genre Dermanyssus (Acari : Mesostigmata). Life Sciences. AgroParisTech,. French. NNT: 2009AGPT0040. pastel-00005531, 2009

33. Shannon C. E.: A Mathematical Theory of Communication. The Bell System Technical Journal, 27, 379-423, 623-656, 1948.

34. Schulz J.: Maßnahmen zur Bekämpfung der Roten Vogelmilbe (Dermanyssus gallinae) in der ökologischen Legehennenhaltung. InauguralDissertation zur Erlangung des Grades eines Doktors der Veterinärmedizin an der Freien Universität Berlin. Berlin 2014 Journal-Nr.: 3702, 2014a. 
35. Schulz J., Berk J., Suhl J., Schrader L., Kaufhold S., Mewis I., Mohammed Hafez H., Ulrichs C.: Characterization, mode of action, and efficacy of twelve silica-based acaricides against poultry red mite (Dermanyssus gallinae) in vitro. Parasitol Research, 113:3167-3175, $2014 \mathrm{~b}$.

36. Sleeckx N., K. Van Hoye, I. Kempen, P. De Herdt, K. De Baere, R. Koopman, S. Van Gorp S., Zoons J.: The Effects of treatment with fluralaner on poultry red mite infestation and on production of laying hens housed in enriched cages and aviaries". Science Parasitol 19, Special issue, 34-35, 2018.

37. Sparagano O.A.E., Pavlićević A., Murano T., Camarda A., Sahibi H., Kilpinen O., Mul M., van Emous R., le Bouquin S., Hoel K., Cafiero M.A.: Prevalence and key figures for the poultry red mite Dermanyssus gallinae infections in poultry farm systems. Experimental and Apply Acarology, 48, 3-10, 2009.

38. Thomas E., Chiquet M., Sander B., Zschiesche1 E., Flochlay A.S.: Field efficacy and safety of fluralaner solution for administration in drinking water for the treatment of poultry red mite (Dermanyssus gallinae) infestations in commercial flocks in Europe. Parasites \& Vectors, 10, 457, 2017. DOI 10.1186/s13071-017-2390-3.

39. Thomas E., Zoller H., Liebisch G., Francisco Angeli Alves L., Vettorato L., Chiummo R.M. Sigognault-Flochlay A.: In vitro activity of fluralaner and commonly used acaricides against Dermanyssus gallinae isolates from Europe and Brazil. Parasites \& Vectors 11, 361, 2018. https://doi.org/10.1186/ s13071-018-2956-8.

40. Technical Manuel: Exzolt, fluralaner. Treatment for poultry red mite infestations in chickens. MSD Animal Health. 2018. www.exzolt.com

41. Zeman P., Zelezny J.: The susceptibility of the poultry red mite Dermanyssus gallinae (De Geer 1778) to some acaricides under laboratory conditions. Experimental and Applied Acarology 1, 17-22, 1985.

42. Zeman, P.: Encounter the poultry red mite resistance to acaricides in Czechoslovak poultry farming. Folia Parasitologica 34, 369-373, 1987.

Primljeno: 13.12 .2018 .

Odobreno: 28.12.2018. 